\title{
Effect of Different Tillage Practices on Growth, Yield and Economics of Chickpea (Cicer arietinum L.) under Rainfed Condition of Chhattisgarh
}

\author{
Tej Ram Banjara ${ }^{1}$, G.P. Pali ${ }^{1}$, Birendra Kumar Tigga ${ }^{1}$, \\ Sunil Kumar ${ }^{2}$ and Abhishek Shori ${ }^{2}$
}

${ }^{1}$ Department of Agronomy, Indira Gandhi Krishi Vishwavidyalaya, Raipur (C.G.)-492012, India

${ }^{2}$ Department of Agronomy, Institute of Agricultural Sciences, BHU, Varanasi-221 005, India

*Corresponding author

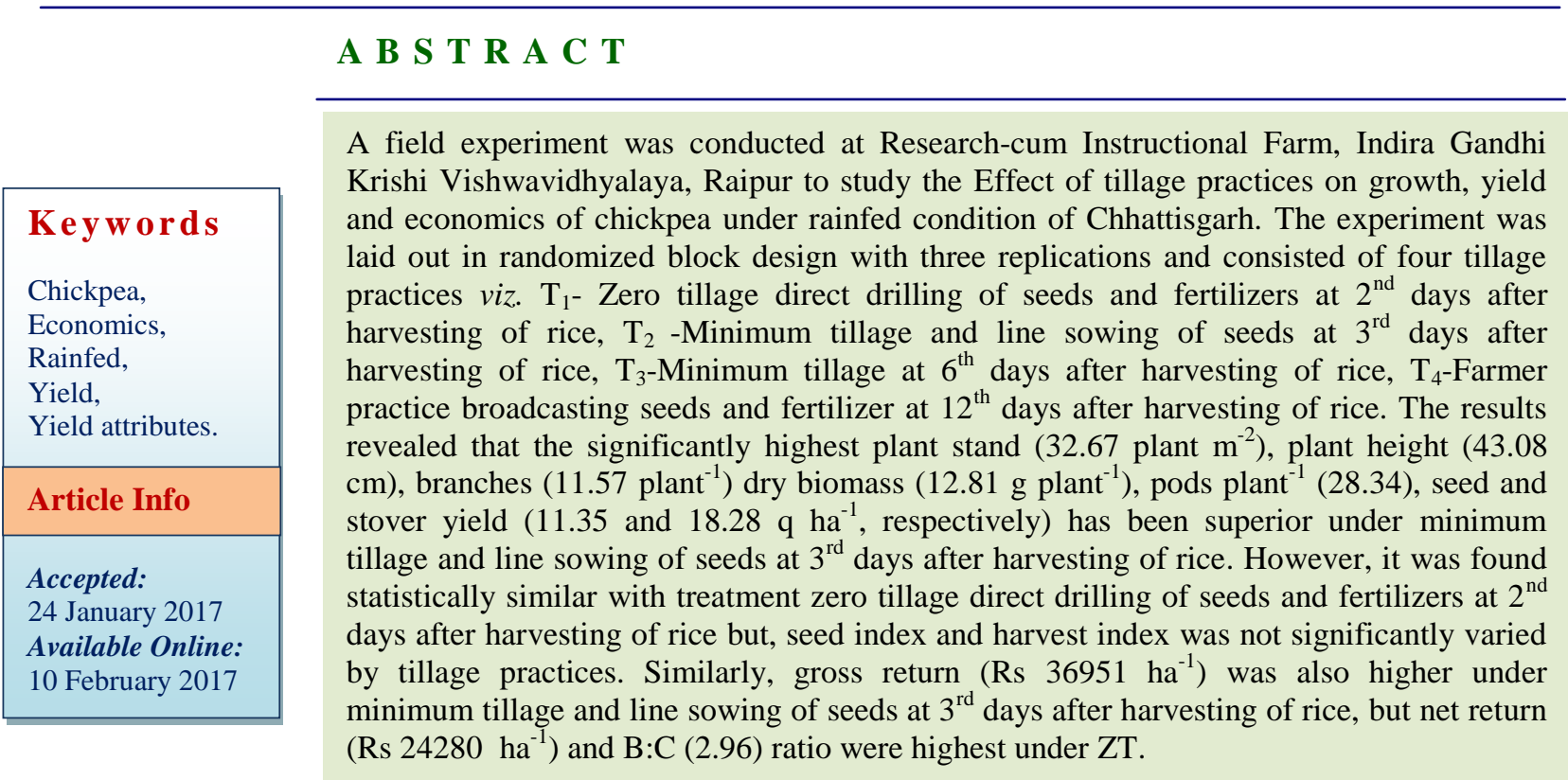

\section{Introduction}

Chickpea (Cicer arietinum L.) is an important winter season pulse crop of India and a key source of protein. In Chhattisgarh, chickpea is grown over an area of 393.78 thousand ha with an annual production of 433.158 thousand tonnes and an average productivity of $1100 \mathrm{~kg} \mathrm{ha}^{-1}$ (Anonymous, 2013-2014). Sequential cropping after harvesting of winter rice is practiced in medium lands (Kushwana and Ali, 1992).In semiarid region of India, expensive and energy consuming tillage operations, declining soil fertility and soil moisture limitation are major constraint for agricultural crop production, In rainy (kharif) season crops are dependent of rainwater while winter (rabi) season crops are dependent on conserved soil moisture (Dhar et al., 2008). It is an important winter season pulse crop of India with drought condition as single most important abiotic constraints of higher productivity (Kumar et al., 2006). Chickpea can increase the productivity both in terms of $\mathrm{N}$ saving from fertilizer source and build up soil fertility through biological source of $\mathrm{N}$ 
(Kumar et al., 1998; Kumar and Prasad, 1999). Chickpea can fix up to $140 \mathrm{~kg} \mathrm{~N} \mathrm{ha}^{-1}$ in a growing period (Poonia and Pithia, 2013). Tillage methods affect the sustainable resources through its influence on soil properties, crop growth and the use of excessive and un-necessary tillage operations is often harmful to soil (Nazeer et al., 2012). The yield increase was correlated with increase in water contents in soil due to decrease in evaporation (Chuadhary et al., 1992). The conservation tillage practices, developed mainly for large scale mechanized agriculture need to be adopted for rainfed pulses in India (Kumar et al., 2006), which are systems of managing crop residue on the soil surface with minimum or no tillage (Unger and McCalla, 1980), are crucial in efficiently saving more precipitation for crop production (Halvorson et al., 2000). In cases where soil moisture limits plant growth, no tillage (direct drilling in untilled soil) has been reported to produce crop yields similar to (Carter and Rennie, 1984) or higher than (Tessier et al., 1990) conventional tillage (various combinations of plowing, disking and cultivation operations to control weeds and to prepare a fine seedbed).The present investigation deals with impact of different tillage practices to alleviate the vagaries of drought on growth, productivity and economics of chickpea.

\section{Materials and Methods}

The present investigation was conducted at research cum instructional farm IGKV Raipur, Chhattisgarh during winter season of 2014-15. The soil of the experimental field was sandy loam in texture (Inceptisols), bulk density $1.48 \mathrm{~g} \mathrm{~m}^{3}(0-15 \mathrm{~cm})$, particle density $2.57 \mathrm{~g} \mathrm{~m}^{3}$ and porosity $41 \%$. Neutral in soil reaction $(6.6 \mathrm{pH})$ and had medium organic carbon $(0.72 \%)$, low available nitrogen (219 $\left.\mathrm{kg} \mathrm{ha}^{-1}\right)$, medium available phosphorus (16.70 $\mathrm{kg} \mathrm{ha}^{-1}$ ) and medium exchangeable potassium
(322.2 $\mathrm{kg} \mathrm{ha}^{-1}$ ) with normal electrical conductivity. The experiment was laid out in randomized block design with three replications and consisted of four tillage practices viz. $\mathrm{T}_{1}$ - Zero tillage direct drilling of seeds and fertilizers at $2^{\text {nd }}$ days after harvesting of rice, $T_{2}$-Minimum tillage and line sowing of seeds at $3^{\text {rd }}$ days after harvesting of rice, $\mathrm{T}_{3}$-Minimum tillage at $6^{\text {th }}$ days after harvesting of rice, $\mathrm{T}_{4}$-Farmer practice broadcasting seeds and fertilizer at $12^{\text {th }}$ days after harvesting of rice. The sowing of crop in treatment $T_{1}, T_{2}, T_{3}$ and $T_{4}$ was done on $31^{\text {st }}$ October, $1^{\text {st }}, 4^{\text {th }}$ and $10^{\text {th }}$ November 2014, respectively and harvesting of crop done 18 February 2015. All recommended package of practices of chickpea crop were adopted during study period. During crop growth period, the maximum temperature varied between $25^{\circ} \mathrm{C}$ to $37.3^{\circ} \mathrm{C}$. The minimum temperature ranged between $8^{0} \mathrm{C}$ to $21.5^{\circ} \mathrm{C}$. The maximum and minimum relative humidity during the crop period was 94 and 22 percent, respectively. A total of $11.7 \mathrm{~mm}$ rainfall was received during the crop period. The data recorded for different characters under investigation were analyzed by following analysis of variance procedure as described by Gomez and Gomez (1984) and Windows-based SPSS program (Version 16.0, SPSS, 2007). The SPSS procedure was used for analysis of variance to determine the statistical significance of treatments effect. The Duncan's multiple-range test was also used to compare treatment means at 5\% probability level.

\section{Results and Discussion}

\section{Growth and development}

Plant population, plant height, number of branches per plant and dry biomass per plant was significantly influenced by different tillage practices (Table 1 and 2). Significantly higher plant population was recorded with 
treatment $T_{2}$ than other treatments, but both the stages of observation, it was statistically at par with treatment $T_{1}$ and lowest plant population was recorded with treatment $T_{4}$. The highest plant population under treatment $\mathrm{T}_{2}$ and $\mathrm{T}_{1}$ might be due to optimum moisture content in soil during seeding and proper placement of seeds by seed drill. Similarly, lowest plant stand observed in treatment $\mathrm{T}_{4}$ might be due to loss of soil moisture at the time of sowing and broadcasting of seeds. Rathore et al., (1998) also observed similar plant stand under zero tillage and minimum tillage. Significantly taller plant at all the crop growth stages were recorded with treatment $\mathrm{T}_{2}$ as compared to rest of the treatments, however, it was found at par with treatment $T_{1}$. The higher plant height under treatment $T_{2}$ might be owing to better availability of soil moisture and nutrients. These observations are also in agreement with the results given by earlier workers (Rathore et al., 1998 and Kumar et al., 2006).Treatment $\mathrm{T}_{2}$ registered significantly higher number of branches plant 1 as compared to other tillage practices. Whereas, treatment $T_{4}$ recorded significantly minimum branches plant ${ }^{-1}$ throughout the crop growth period. Similar results were also recorded by Kumar et al., (2006). They observed significantly higher number of branches plant $^{-1}$ in compact tillage than normal tillage practice. On the contrary, Savu (2007) reported that the conventional tillage produced significantly higher number of branches as compared to zero tillage. Throughout the life span of crop, significantly highest dry biomass was recorded under treatment $\mathrm{T}_{2}$ but at $30 \mathrm{DAS}$ it was at par with treatment $T_{1}$. However, significantly lowest dry biomass was recorded with the treatment $\mathrm{T}_{4}$ throughout the crop growth period. The highest dry biomass under treatment $\mathrm{T}_{1}$ and $\mathrm{T}_{2}$ might be due to good availability of moisture which is evidenced by higher plant height and branches plant ${ }^{-1}$. These results are in line with finding of Rathore et al., (1998) and Kumar et al., (2006) who also observed the highest dry biomass under zero tillage.

\section{Number of root nodules plant ${ }^{-1}$ and dry weight of root nodules ( $\mathrm{mg} \mathrm{plant}^{-1}$ )}

The number of root nodules plant ${ }^{-1}$ and dry weight of root nodules ( $\mathrm{mg}$ plant $^{-1}$ )observed at 30, 45, 60, 75 and 90 DAS and it was significantly influenced by tillage practices (Table 3 and 4). Significantly higher number of root nodules plant ${ }^{-1}$ was observed with treatment $T_{2}$ as compared to others at all the stages of observation. However, it was found at par with treatment $T_{3}$ at 30, 45, 60 and 75 DAS. While, significantly lower number of root nodules plant $^{-1}$ was observed with treatment $T_{4}$ at all the period of observation more number of nodules plant ${ }^{-1}$ may probably be due to better seedbed preparation which facilitated better root growth ultimately more number of nodules plant ${ }^{-1}$ were registered. The dry weight of root nodules was significantly higher under treatment $\mathrm{T}_{2}$ as compared to other tillage practices at 30,45 , 60 and 75 DAS. However, at 90 DAS, dry weight of root nodules was significantly higher under above treatment, but it was found statistically at par with the treatment $\mathrm{T}_{3}$. Higher dry weight of root nodules may be owing to maximum number of nodules plant ${ }^{-1}$ in treatment $\mathrm{T}_{2}$.

\section{Yield attributes}

Tillage practices brought significant difference on number of pods plant ${ }^{-1}$. The significantly higher number of pods plant ${ }^{-1}$ (28.34) was observed with treatment $\mathrm{T}_{2}$ as compared to rest of the treatments (Table 5). The highest number of pods plant $^{-1}$ with treatment $\mathrm{T}_{2}$ which is evidence by more branching. Similar finding have also been recorded by Kumar et al., (2006). However, tillage practices did not bring significant difference on seeds pod $^{-1}$ and seed index $(\mathrm{g})$. 
Table.1 Effect of tillage practices on plant population and growth parameters of chickpea

\begin{tabular}{|c|c|c|c|c|c|c|}
\hline \multirow{2}{*}{ Treatment } & \multicolumn{2}{|c|}{ Plant population $\left.\mathbf{( m}^{-\mathbf{2}}\right)$} & \multicolumn{4}{|c|}{ Plant height $(\mathbf{c m})$} \\
\cline { 2 - 7 } & $\begin{array}{c}\mathbf{2 5} \\
\text { DAS }\end{array}$ & $\begin{array}{c}\mathbf{A t} \\
\text { harvest }\end{array}$ & $\begin{array}{c}\mathbf{3 0} \\
\text { DAS }\end{array}$ & $\begin{array}{c}\mathbf{6 0} \\
\text { DAS }\end{array}$ & 90 DAS & At harvest \\
\hline $\mathbf{T}_{\mathbf{1}}$ & $41.52 \mathrm{a}$ & $31.56^{\mathrm{a}}$ & $21.17^{\mathrm{a}}$ & $36.02^{\mathrm{ab}}$ & $38.03^{\mathrm{ab}}$ & $40.90^{\mathrm{ab}}$ \\
\hline $\mathbf{T}_{\mathbf{2}}$ & $43.00^{\mathrm{a}}$ & $32.67^{\mathrm{a}}$ & $21.53^{\mathrm{a}}$ & $37.87^{\mathrm{a}}$ & $39.19^{\mathrm{a}}$ & $42.08^{\mathrm{a}}$ \\
\hline $\mathbf{T}_{\mathbf{3}}$ & $35.69^{\mathrm{b}}$ & $28.78^{\mathrm{b}}$ & $19.20^{\mathrm{b}}$ & $34.87^{\mathrm{b}}$ & $37.04^{\mathrm{b}}$ & $38.03^{\mathrm{bc}}$ \\
\hline $\mathbf{T}_{\mathbf{4}}$ & $34.41^{\mathrm{b}}$ & $24.87^{\mathrm{c}}$ & $18.80^{\mathrm{b}}$ & $33.25^{\mathrm{b}}$ & $35.28^{\mathrm{c}}$ & $36.02^{\mathrm{c}}$ \\
\hline
\end{tabular}

Table.2 Effect of tillage practices on branches plant- 1 and dry biomass plant- 1 of chickpea

\begin{tabular}{|c|c|c|c|c|c|c|c|c|}
\hline \multirow{2}{*}{ Treatment } & \multicolumn{4}{|c|}{ Branches plant $^{-1}$} & \multicolumn{3}{c|}{ Dry biomass plant $^{-1}(\mathbf{g})$} \\
\cline { 2 - 9 } & $\mathbf{3 0}^{-1}$ DAS & $\begin{array}{c}\mathbf{6 0} \\
\text { DAS }\end{array}$ & 90 DAS & At harvest & 30 DAS & $\begin{array}{c}\text { 60 } \\
\text { DAS }\end{array}$ & 90 DAS & $\begin{array}{c}\text { At } \\
\text { harvest }\end{array}$ \\
\hline $\mathbf{T}_{\mathbf{1}}$ & $2.07^{\mathrm{b}}$ & $8.74^{\mathrm{b}}$ & $9.98^{\mathrm{bc}}$ & $9.95^{\mathrm{bc}}$ & $0.45^{\mathrm{a}}$ & $5.21^{\mathrm{b}}$ & $9.21^{\mathrm{b}}$ & $11.30^{\mathrm{b}}$ \\
\hline $\mathbf{T}_{\mathbf{2}}$ & $2.33^{\mathrm{a}}$ & $\begin{array}{c}10.99 \\
{ }^{\mathrm{a}}\end{array}$ & $11.65^{\mathrm{a}}$ & $11.57^{\mathrm{a}}$ & $0.46^{\mathrm{a}}$ & $5.55^{\mathrm{a}}$ & $10.03^{\mathrm{a}}$ & $12.81^{\mathrm{a}}$ \\
\hline $\mathbf{T}_{\mathbf{3}}$ & $1.73^{\mathrm{b}}$ & $9.54^{\mathrm{b}}$ & $10.78^{\mathrm{ab}}$ & $10.77^{\mathrm{ab}}$ & $0.41^{\mathrm{b}}$ & $5.03^{\mathrm{b}}$ & $9.12^{\mathrm{b}}$ & $10.93^{\mathrm{b}}$ \\
\hline $\mathbf{T}_{\mathbf{4}}$ & $1.73^{\mathrm{c}}$ & $7.82^{\mathrm{c}}$ & $9.06^{\mathrm{c}}$ & $9.05^{\mathrm{c}}$ & $0.36^{\mathrm{c}}$ & $4.80^{\mathrm{c}}$ & $8.19^{\mathrm{c}}$ & $9.45^{\mathrm{c}}$ \\
\hline
\end{tabular}

$\mathrm{T}_{1}-$ Zero tillage direct drilling of seeds at $2^{\text {nd }} \quad \mathrm{T}_{2}-$ Minimum tillage and line sowing of seeds

$\mathrm{DAH}$ of rice

$\mathrm{T}_{3}$ - Minimum tillage and line sowing of seeds at $6^{\text {th }} \mathrm{DAH}$ of rice at $3^{\text {rd }} \mathrm{DAH}$ of rice

$\mathrm{T}_{4}$ - Farmer's practice - seeds and fertilizers broadcasting at $12^{\text {th }} \mathrm{DAH}$ of rice

Table.3 Numbers of root nodule plant-1 and dry weight (mg) of root nodules plant-1 as influenced by tillage practices

\begin{tabular}{|c|c|c|c|c|c|}
\hline \multirow{2}{*}{ Treatment } & \multicolumn{5}{|c|}{ No. of root nodules plant } \\
\cline { 2 - 5 } & \multirow{2}{*}{ 30 DAS } & \multirow{3}{*}{$\mathbf{3 0}$ DAS } & 30 DAS & \multirow{2}{*}{ 30 DAS } & \multirow{2}{*}{ 30 DAS } \\
\hline $\mathbf{T}_{\mathbf{1}}$ & $9.00^{\mathrm{b}}$ & $9.00^{\mathrm{b}}$ & $9.00^{\mathrm{b}}$ & $9.00^{\mathrm{b}}$ & $9.00^{\mathrm{b}}$ \\
\hline $\mathbf{T}_{\mathbf{2}}$ & $9.96^{\mathrm{a}}$ & $9.96^{\mathrm{a}}$ & $9.96^{\mathrm{a}}$ & $9.96^{\mathrm{a}}$ & $9.96^{\mathrm{a}}$ \\
\hline $\mathbf{T}_{\mathbf{3}}$ & $9.28^{\mathrm{ab}}$ & $9.28^{\mathrm{ab}}$ & $9.28^{\mathrm{ab}}$ & $9.28^{\mathrm{ab}}$ & $9.28^{\mathrm{ab}}$ \\
\hline $\mathbf{T}_{\mathbf{4}}$ & $8.34^{\mathrm{c}}$ & $8.34^{\mathrm{c}}$ & $8.34^{\mathrm{c}}$ & $8.34^{\mathrm{c}}$ & $8.34^{\mathrm{c}}$ \\
\hline
\end{tabular}

Table.4 Numbers of root nodule plant-1 and dry weight (mg) of root nodules plant-1 as influenced by tillage practices

\begin{tabular}{|c|c|c|c|c|c|}
\hline \multirow{2}{*}{ Treatment } & \multicolumn{4}{|c|}{ Dry weight (mg) of root nodules plant } \\
\cline { 2 - 5 } & \multirow{2}{*}{ 30 DAS } & 45 DAS & 60 DAS & 75 DAS & \multirow{2}{*}{ 90 DAS } \\
\hline $\mathbf{T}_{\mathbf{1}}$ & $8.36^{\mathrm{b}}$ & $28.10^{\mathrm{b}}$ & $50.67^{\mathrm{b}}$ & $48.23^{\mathrm{b}}$ & $6.50^{\mathrm{b}}$ \\
\hline $\mathbf{T}_{\mathbf{2}}$ & $10.57^{\mathrm{a}}$ & $33.70^{\mathrm{a}}$ & $60.33^{\mathrm{a}}$ & $56.00^{\mathrm{a}}$ & $7.67^{\mathrm{a}}$ \\
\hline $\mathbf{T}_{\mathbf{3}}$ & $9.43^{\mathrm{b}}$ & $29.45^{\mathrm{b}}$ & $54.70^{\mathrm{b}}$ & $50.23^{\mathrm{b}}$ & $7.28^{\mathrm{b}}$ \\
\hline $\mathbf{T}_{\mathbf{4}}$ & $8.64^{\mathrm{c}}$ & $28.74^{\mathrm{c}}$ & $52.34^{\mathrm{b}}$ & $48.32^{\mathrm{b}}$ & $6.10^{\mathrm{c}}$ \\
\hline
\end{tabular}


Table.5 Yield attributes and yields of chickpea as influenced by tillage practices

\begin{tabular}{|c|c|c|c|c|c|c|}
\hline Treatment & $\begin{array}{l}\text { No. of pods } \\
\text { plant }^{-1}\end{array}$ & $\begin{array}{l}\text { No. of seeds } \\
\text { pod }^{-1}\end{array}$ & $\begin{array}{c}\text { Seed index } \\
(\mathrm{g})\end{array}$ & $\begin{array}{c}\text { Seed yield } \\
\left(\mathrm{q} \mathbf{h a}^{-1}\right)\end{array}$ & $\begin{array}{c}\text { Stover yield } \\
\left(\mathrm{q} \mathrm{ha}^{-1}\right)\end{array}$ & $\begin{array}{c}\text { HI } \\
(\%)\end{array}$ \\
\hline$T_{1}$ & $23.45^{\mathrm{b}}$ & 1.27 & 22.43 & $11.09^{\mathrm{a}}$ & $15.53 \mathrm{~b}$ & 39.70 \\
\hline $\mathbf{T}_{2}$ & $28.34^{\mathrm{a}}$ & 1.27 & 22.47 & $11.35^{\mathrm{a}}$ & $18.28^{\mathrm{a}}$ & 38.30 \\
\hline$T_{3}$ & $22.64^{b}$ & 1.20 & 22.47 & $9.30^{\mathrm{b}}$ & $14.46^{\mathrm{b}}$ & 39.13 \\
\hline $\mathbf{T}_{4}$ & $18.26^{\mathrm{c}}$ & 1.20 & 22.32 & $7.15^{\mathrm{c}}$ & $11.37^{\mathrm{c}}$ & 38.66 \\
\hline
\end{tabular}

Table.6 Economics of chickpea as influenced by tillage practices

\begin{tabular}{|c|c|c|c|c|}
\hline Treatment & $\begin{array}{c}\text { Cost of cultivation (Rs. } \\
\mathbf{h a}^{-\mathbf{1}} \text { ) }\end{array}$ & $\begin{array}{c}\text { Gross return (Rs. } \\
\left.\mathbf{h a}^{-\mathbf{1}}\right)\end{array}$ & $\begin{array}{c}\text { Net return (Rs. } \\
\left.\mathbf{h a}^{-\mathbf{1}}\right)\end{array}$ & B:C ratio \\
\hline $\mathbf{T}_{\mathbf{1}}$ & 12337 & $36545^{\mathrm{a}}$ & $24208^{\mathrm{a}}$ & $2.96^{\mathrm{a}}$ \\
\hline $\mathbf{T}_{\mathbf{2}}$ & 14237 & $36951^{\mathrm{a}}$ & $22713^{\mathrm{a}}$ & $2.60^{\mathrm{b}}$ \\
\hline $\mathbf{T}_{\mathbf{3}}$ & 14237 & $30631^{\mathrm{b}}$ & $16394^{\mathrm{b}}$ & $2.15^{\mathrm{c}}$ \\
\hline $\mathbf{T}_{\mathbf{4}}$ & 15237 & $23661^{\mathrm{c}}$ & $8424^{\mathrm{c}}$ & $1.55^{\mathrm{d}}$ \\
\hline
\end{tabular}

Seeds pod $^{-1}$ was varied from $1.13-1.27$. The highest number of seeds $\operatorname{pod}^{-1}(1.27)$ was noted under both the treatment $\mathrm{T}_{1}$ and $\mathrm{T}_{2}$. Whereas, the lowest number of seeds plant ${ }^{-1}$ (1.13) was noted with treatment $\mathrm{T}_{4}$.

\section{Yield}

The perusal of data given in table 5 reveal that the significantly highest seed yield and stover yield (11.35 and $18.28 \mathrm{q} \mathrm{ha}^{-1}$ ) was obtained under treatment $\mathrm{T}_{2}$, but seed yield was found at par to treatment $\mathrm{T}_{1}$. The lowest seed yield and stover yield (7.15 and $11.37 \mathrm{q} \mathrm{ha}^{-1}$ ) was obtained under treatment $\mathrm{T}_{4}$. The significantly higher seed yield and stover yield was recorded in treatment $T_{2}$ and $T_{1}$ as compared to treatment $\mathrm{T}_{4}$, which is evident by more number of branches plant ${ }^{-1}$, higher dry weight plant $^{-1}$ and more number of pods plant ${ }^{-1}$. Similar results have also been reported by Rathore et al., (1998) and Hemmat and Eskandari (2004) and Kumar et al., (2006) and Yau et al., (2010). Harvest index (\%) did not show any variation by different tillage practices. But, highest harvest index $(39.70$ $\%$ ) was recorded under treatment $\mathrm{T}_{1}$ followed by $\mathrm{T}_{3}$ and the lowest harvest index (38.30\%) was recorded in treatment $T_{2}$.

\section{Economics}

Cost of cultivation, gross return, net return and $\mathrm{B}$ : $\mathrm{C}$ ratio varied due to tillage practices (Table 6) The highest cost of cultivation (Rs. $15237 \mathrm{ha}^{-1}$ ) was involved in treatment $\mathrm{T}_{4}$ followed by $T_{2}$ and $T_{3}$. Treatment $T_{2}$ gave the highest gross return (Rs. $36951 \mathrm{ha}^{-1}$ ) but, net return (Rs. 24208 ha $^{-1}$ ) and B: C ratio (2.96) were highest recorded under treatment $\mathrm{T}_{1}$ followed by $T_{2}$ and $T_{3}$ due to reduction in cost of cultivation in conservation tillage. Dhar et al., (2008) also recorded highest yield under zero tillage practice.

In conclusion, on the basis of experiment results, it is concluded that minimum tillage and line sowing of seeds at $3^{\text {rd }}$ days after harvesting of rice may be the better tillage practice for growing of the chickpea in midland rainfed condition of Chhattisgarh region as minimum tillage treatment recorded higher grain yield and economics comparison to the rest of the tillage practices studied. 


\section{References}

Anonymous. 2013-2014. Krishi Darshika, I.G.K.V., Raipur, (C.G.) 4.

Arya, R.L., Kumar, L., Singh, K.K. and Kushwaha, B.L. 2005. Effect of fertilizers and tillage management in rice (Oryza sativa)-chickpea (Cicer arietinum) cropping system under varying irrigation schedules. Indian $J$. Agronomy, 50 (4): 256-259

Carter, M.R., Rennie, D.A. 1984. Nitrogen transformations under zero and shallow tillage. Soil Sci. Society of American J., 48: 1077-1081

Chuadhary, A. D., Yasin, M. and Rashid, M. 1992. Evaluation of rainfed rice to farm yard maunure and soil compaction. Int. Rice Res., Newsletter, IRRI, Philipines, 11: 32 .

Das, N.R. and Das, D. 1998. Effect of tillage number on yields of rainfed winter crops in rice-fallows of West Bengal. Adv. Agri. Res. India, 9: 113-117.

Dhar, S., Das, S.K., Kumar, S. and Singh, J.B. 2008. Effect of tillage and soil moisture conservation practices on crop yield of chickpea (Cicer arietinum) and soil properties under rainfed conditions. Indian J. Agri. Sci., 78(12): 1042-53.

Eduardo, M. 2008. Soil physical properties and wheat root growth as affected by no-tillage and conventional tillage systems in a Mediterranean environment of Chile. Soil and Tillage Res., In Press Corrected Proof Available online 2 April.

Gomez, K.A. and Gomez, A.A. 1984. Statistical procedures for agricultural research. A Willey- Inter Sci. Publication. John Willey \& Sons, New York.

Halvorson, A.D., Black, A.L., Krupinsky, J.M., Merrill, S.D., Wienhold, B.J., Tanaka, D.L. 2000. Spring wheat response to tillage system and nitrogen fertilization in rotation with sunflower and winter wheat. Agronomy J., 92: 136-144.

Hassan, G., Khan, N. and Khan, H. 2003. Effect of zero tillage and herbicides on the weed density and yield of chickpea under rice-based conditions. Pakistan J. Weed Sci. Res., 9(3-4): 193-200.

Hemmat, A. and Eskandari, I. 2004. Tillage system effects upon productivity of a dryland winter wheat-chickpea rotation in the northwest region of Iran. Soil and Tillage Res., 78 (1): 69-81.

Khan, I.A. 2010.Tillage and seed rates effect on weed biomass, grain and biological yield of dryland chickpea. Pakistan J. Bot., 42(6): 4011-4016.

Kumar Rao, J.D.V.K., Johanson, C. and Rago, T.J. 1998. Eds. Residual effects of legume in rice-wheat cropping systems of the Indo-Gangetic plain. International Crops Research Institute for the Semi-Arid Tropics, Andhra Pradesh, India, 250.

Kumar, R., Arya, R.L. and Mishra, J.P. 2006. Effect of seed priming and tillage management on productivity of chickpea genotype under rainfed conditions. Indian J. Agronomy, 51 (1): 54-56.

Kumar, S. and Prasad, N.K. 1999. Soil fertility and yields as influenced by different legume-wheat (Triticum aestivum) sequence. Indian $J$. Agronomy, 44 (3): 488-492.

Kushwaha, B. L. and Ali, M. 1992. Nutrient management of pulses in rice fallows of eastern India. In) Compilation of Talks, Summer Institute on Management of Pulses in cropping system held during 19 May-7 June 1992, Directorate of Pulses Research, Kanpur: 78-83.

Nazeer, S., A.U. Malik, Nazir, G. and Ahmad, J. 2012.Effectiveness of tillage systems and farm manure levels on rice productivity. The J. Animal \& Plant 
Sci., 22(2): 334-338.

Poonia, T.C. and Pithia, M.S. 2013. Pre- and post-emergence herbicides for weed management in chickpea. Indian $J$. Weed Sci., 45(3): 223-225.

Rathore, A.L., Pal, A.R. and Sahu K.K. 1998. Tillage and mulching effects on water use, root growth and yield of rainfed mustard and chickpea growth after lowland rice. J. Science of Food and Agriculture, 78: 149-61.

Savu, R.M. 2007. Studies on establishment and performance of rabi crops under rainfed and limited irrigation conditions in rice and soybean based cropping system. Ph. D. Thesis, Indira Gandhi Krishi Vishwavidyalaya, Raipur, 96.

Tessier, S., Peru, M., Dyck, F.B., Zentner, F.P., Campbell, C.A., (1990. Conservation tillage for spring wheat in semi-arid Saskatchewan. Soil and Tillage Res., 18, 73-89.

Unger, P.W., McCalla, T.M., (1980. Conservation tillage systems. $A d v$. Agronomy, 33: 1-58.

Yau, S.K., Sidahmed, M. and Haidar, M. 2010. Conservation versus conventional tillage on performance of three different crops. Agronomy J., 102(1): 269-276.

\section{How to cite this article:}

Tej Ram Banjara, G.P. Pali, Birendra Kumar Tigga, Sunil Kumar and Abhishek Shori. 2017. Effect of Different Tillage Practices on Growth, Yield and Economics of Chickpea (Cicer arietinum L.) under Rainfed Condition of Chhattisgarh. Int.J.Curr.Microbiol.App.Sci. 6(2): 1464-1470. doi: http://dx.doi.org/10.20546/ijcmas.2017.602.164 